\title{
STRUKTURA RAZLIČITIH INDIKATORA IZOMETRIJSKE EKSPLOZIVNE SILE OPRUŽAČA NOGU KOD VRHUNSKIH SPORTISTA
}

\author{
Jelena Ivanović ${ }^{1}$ i Milivoj Dopsaj ${ }^{2}$
}

${ }^{1}$ Zavod za sport i medicinu sporta Republike Srbije, Beograd, Srbija

${ }^{2}$ Fakultet sporta i fizičkog vaspitanja, Univerzitet Beograd, Srbija

\section{SAŽETAK}

Cilj ovog rada bio je utvrditi faktorsku strukturu posmatranih karakteristike tj. indikatora krive sila-vrijeme za procjenu eksplozivnosti opružača nogu u odnosu na različite grupe sportova. U istraživanju je učestvovalo 378 ispitanika raspoređenih u 8 grupa prema polu i specifičnosti trenažnog procesa kojem su bili izloženi. Za procjenu kontraktilnih karakteristika opružača nogu korišćena je standardizovana oprema i standardizovan test u sjedećoj poziciji. Mjerni opseg definisan je na osnovu 15 varijabli koje se odnose na kontraktilne karakteristike izometrijske eksplozivne sile ekstenzora nogu mjerene u unilateralnom (dominanta i nedominanta noga) i bilateralnom režimu mišićne kontrakcije mjerenih na 100 i 50\% od maksimalne sile i na 100, 180 i 250 ms od početka mišićne kontrakcije. Rezultati dobijeni u ovom istraživanju pokazuju da mjerene karakteristike eksplozivne sile opružača nogu dobijene u bi i unilateralnom režimu naprezanja u odnosu na različite grupe sportova imaju različitu strukturu u funkciji izdvojenog sklopa faktora pod uticajem drugačijih mehanizama u odnosu na trenažne procese u različitim sportskim disciplinama.

Ključne riječi: faktorska struktura, različito trenirani sportisti, kriva sila-vrijeme.

\section{UVOD}

U metrološkim procedurama u sportu (procedure testiranja) pored utemeljenih standarda o mjerenju maksimalnih vrednosti $F-t$ krive, prepoznatih u vrijednostima maksimalne izometrijske sile $\left(\mathrm{F}_{\text {max }}\right)$, opštem pokazatelju eksplozivnosti $\left(\mathrm{RFDF}_{\text {max }}\right)$ i opštem indeksu sinergije $\left(\mathrm{I}_{\text {ndx }} \mathrm{SNG}_{\text {BASIC }}\right)$ neophodno je usvojiti i specifične i specijalne karakteristike $F$ - $t$ krive, odnosno specijalne i specifične pokazatelje eksplozivnosti. Činjenica je da za vrijeme izvođenja maksimalno brzih pokreta ekstremiteta nije moguće ostvarivanje apsolutnih vrijednosti maksimalnih sila na nivou punog kontraktilnog potencijala angažovanog mišića. Vrhunski sportisti u takmičarskim uslovima najčešće realizuju pokrete u vremenskom intervalu do $300 \mathrm{~ms}$ (Andersen i Aagaard, 2006). Zbog toga se svaki vid usmjerene i specifične fizičke pripremljenosti treba bazirati na povećanju određene karakteristike eksplozivnosti $\left(\mathrm{RFD}_{\max }\right)$, sa tendencijom povećanja iste upravo u specifičnom vremenskom intervalu izvođenja datih pokreta, odnosno u ranoj fazi mišićne kontrakcije (Andersen, Andersen, Zebis i Aagaard, 2010; Hakkinen, Komi i Kauhanen, 1987; Ivanović, Dopsaj, Ćopić i Nešić, 2011; Mero, 1988).

Svrsishodnost samih rezultata o utreniranosti sportiste i nivou razvijenosti testiranih fizičkih svojstava direktno zavisi od primjenjenog testa i njegove specifičnosti i osetljivosti mjerenja. Što je test više specifičan u odnosu na sportsku granu u kojoj se sportista takmiči, informacije prikupljene tokom testiranja validnije su za procjenu realnog stanja pripremljenosti (Müller, Benko, Raschner, \& Schwameder, 2000; Зациорски, 1982; Wilson \& Murphy, 1996). Jedan od zadataka ovog istraživanja je upravo i pronalaženje i verifikacija boljih, tj. validnijih i reprezentativnijih mjera za procjenu konraktilnih karakteristika izometrijske sile opružača nogu kod različito treniranih vrhunskih sportista. Otkrivanjem stukture prostora definisanog kao kontraktilne karakteristike izometrijske sile opružača nogu omogućilo bi se otkrivanje zakonitosti koje vladaju između ele- 
menata sistema u odnosu na različito trenirane populacije što bi trebalo posledično dovesti i do generalno preciznijeg upravljanja trenažnim procesom sa aspekta različitih sportskih disciplina i u funkciji pola. Pored toga, s obzirom da se u sportu koriste sva tri oblika opterećenja tokom kretanja, poznato je da lokomocija tipa trčanja, odskoka, doskoka, promjene pravaca čini sistem bi i unilateralnog naprezanja, u ovom radu će se kontraktilne karakteristike opružača nogu posmatrati u sva tri režima mišićne kontrakcije.

Predloženim pristupom analize podataka dobijenih mjernim instrumentom za mjerenje sile ekstenzora nogu u sjedećoj poziciji u uslovima bilateralnog i unilateralnog izometrijskog naprezanja utvrdiće se zakonitosti koje važe među ispitivanim svojstvima sistema različito treniranih sportista - kontraktilne karakteristike sile, upotpuniće se saznanja potrebna za usavršavanje tehnološkog procesa treninga u različitim sportskim disciplinama.

Cilj ovog rada je utvrđivanje faktorske strukture posmatranih karakteristika, tj. indikatora $F$ - $t$ krive za procjenu eksplozivnosti opružača nogu u odnosu na različite grupe sportova.

\section{METODE}

U ovom istraživanju je učestvovalo 378 ispitanika raspoređenih u 8 grupa prema polu i specifičnosti

TABELA 1

Osnovni deskriptivni pokazatelji oba pola u odnosu na rąlicite grupe sportova.

\begin{tabular}{|c|c|c|c|c|c|c|c|c|c|c|}
\hline & \multicolumn{5}{|c|}{ Muškraci } & \multicolumn{5}{|c|}{ Žene } \\
\hline & $\begin{array}{l}\mathrm{BM} \\
(\mathrm{kg})\end{array}$ & $\begin{array}{l}\mathrm{BH} \\
(\mathrm{cm})\end{array}$ & $\begin{array}{c}\text { BMI } \\
\left(\mathrm{kg} / \mathrm{m}^{2}\right)\end{array}$ & $\begin{array}{c}\text { A } \\
\text { (yeras) }\end{array}$ & $\begin{array}{c}\text { TP } \\
\text { (years) }\end{array}$ & $\begin{array}{l}\mathrm{BM} \\
(\mathrm{kg})\end{array}$ & $\begin{array}{l}\mathrm{BH} \\
(\mathrm{cm})\end{array}$ & $\begin{array}{c}\text { BMI } \\
\left(\mathrm{kg} / \mathrm{m}^{2}\right)\end{array}$ & $\begin{array}{c}\text { A } \\
\text { (yeras) }\end{array}$ & $\begin{array}{c}\mathrm{TP} \\
\text { (years) }\end{array}$ \\
\hline \multicolumn{11}{|c|}{ Brzinsko-snažni sportovi (muškarci $n=40$; žene $n=34$ ) } \\
\hline M & 80,61 & 182,10 & 24,23 & 21,48 & 10,95 & 66,44 & 169,29 & 23,16 & 21,65 & 11,06 \\
\hline$S D$ & 13,81 & 7,72 & 3,33 & 3,43 & 3,34 & 19,52 & 7,41 & 6,92 & 3,32 & 3,19 \\
\hline$c V \%$ & 17,13 & 4,24 & 13,73 & 15,99 & 30,46 & 29,37 & 4,38 & 29,86 & 15,34 & 28,85 \\
\hline Min & 59,00 & 169,00 & 18,01 & 18,00 & 8,00 & 50,00 & 154,00 & 17,41 & 18,00 & 8,00 \\
\hline $\operatorname{Max}$ & 130,00 & 203,00 & 37,18 & 31,00 & 20,00 & 163,20 & 184,00 & 60,38 & 29,00 & 22,00 \\
\hline
\end{tabular}

Sportovi sa kompleksnim ispoljavanjem svih motoričkih svojstava (muškarci $n=99$; žene $n=43$ )

\begin{tabular}{lrrrrrrrrrr}
\hline$M$ & 83,35 & 183,97 & 24,57 & 22,24 & 11,87 & 67,49 & 175,45 & 21,89 & 21,16 & 11,27 \\
\hline$S D$ & 11,60 & 6,97 & 2,66 & 4,31 & 3,72 & 8,92 & 10,42 & 1,92 & 2,79 & 2,83 \\
\hline$c V \%$ & 13,92 & 3,79 & 10,84 & 19,37 & 31,38 & 13,22 & 5,94 & 8,87 & 13,16 & 25,11 \\
\hline Min & 51,00 & 162,00 & 18,87 & 17,00 & 8,00 & 53,00 & 158,00 & 18,59 & 17,00 & 7,00 \\
\hline Max & 115,00 & 201,00 & 33,60 & 35,00 & 27,00 & 87,40 & 196,00 & 26,99 & 27,00 & 18,00 \\
\hline
\end{tabular}

Sportovi izdržljivosti (muškarci $n=64$; žene $n=33$ )

\begin{tabular}{lrrrrrrrrrr}
\hline$M$ & 82,36 & 186,67 & 23,57 & 23,88 & 11,27 & 60,91 & 171,70 & 20,57 & 22,45 & 8,97 \\
\hline$S D$ & 10,18 & 8,02 & 1,80 & 5,04 & 3,58 & 8,61 & 7,31 & 1,69 & 5,48 & 1,76 \\
\hline$c V \%$ & 12,36 & 4,30 & 7,62 & 21,11 & 31,76 & 14,13 & 4,26 & 8,19 & 24,42 & 19,61 \\
\hline Min & 65,00 & 171,00 & 18,52 & 17,00 & 8,00 & 48,00 & 160,00 & 17,99 & 17,00 & 7,00 \\
\hline $\operatorname{Max}$ & 105,00 & 204,00 & 29,71 & 37,00 & 25,00 & 82,00 & 186,00 & 24,39 & 37,00 & 14,00 \\
\hline
\end{tabular}

Kontrolna grupa (muškarci $n=33$; žene $n=32$

\begin{tabular}{lrrrrrrrr}
\hline$M$ & 80,93 & 181,24 & 24,57 & 24,77 & 60,36 & 167,63 & 21,47 & 23,16 \\
\hline$S D$ & 10,91 & 5,59 & 2,51 & 5,09 & 6,29 & 6,18 & 1,91 & 4,69 \\
\hline$c$ \% & 13,48 & 3,08 & 10,20 & 20,55 & 10,42 & 3,68 & 8,91 & 20,26 \\
\hline Min & 56,00 & 171,00 & 19,15 & 18,00 & 47,00 & 155,00 & 18,42 & 18,00 \\
\hline Max & 109,00 & 197,00 & 30,51 & 34,00 & 75,00 & 180,00 & 28,04 & 34,00 \\
\hline
\end{tabular}

Legenda: BM - Tjelesna masa; BH - Tjelesna visina; BMI - Indeks tjelesne mase; A - Uzrast; TP - Sportski staž; $M$ - Aritmetička sredina; $S D$ - Standardna devijacija; $c V \%$ - Koeficijent varijacije; Min - Minimum; Max - Maksimum; $\boldsymbol{n}$ - Broj ispitanika. 
trenažnog procesa kojem su podvrgnuti: vrhunski sportisti iz grupe brzinsko-snažnih sportova (različite bacačke, skakačke i sprinterske, do $400 \mathrm{~m}$, discipline atletike, dizači tegova, gimnastičari, skijaši i sprinterske discipline, do $200 \mathrm{~m}$, u plivanju; muškarci $n=40 \mathrm{i}$ žene $n=34$ ), vrhunski sportisti iz grupe sportova s kompleksnim ispoljavanjem svih motoričkih svojstava (odbojka, rukomet, košarka, fudbal, vaterpolo i borilačkim sportovima - džudo, rvanje, boks, tekvondo, mačevanje; muškarci $n=99$ i žene $n=43$ ), vrhunski sportisti iz grupe sportova izdržljivosti (atletske discipline, srednje i dugoprugaši, veslači, određene plivačke discipline, preko $400 \mathrm{~m}$, biciklisti i triatlonci; muškarci $n=64$ i žene $n=33)$ i kontrolna grupa sačinjena od netreniranih osoba muškog i ženskog pola (muškarci $n=33$ i žene $n=32$ ). U odnosu na pol, uzorak ispitanika ženskog pola činilo je ukupno 142 ispitanica a uzorak ispitanika muškog pola 236.

\section{Varijable}

Mjerni opseg definisan je na osnovu 15 varijabli koje se odnose na kontraktilne karakteristike izometrijske sile ekstenzora nogu merene u unilateralnom (dominantna - $\mathrm{RFD}_{\mathrm{DO}}$ i nedominantna $-\mathrm{RFD}_{\mathrm{ND}}$ noga) i bilateralnom (RFD) režimu mišićne kontrakcije:

- Pokazatelj opšteg ili bazičnog nivoa razvijenosti eksplozivne sile tj. eksplozivnosti opružača nogu bilateralno i unilateralno (dominantne i nedominantne noge), dobijen je na osnovu sljedeće procedure (Ivanović, Dopsaj i Nešić, 2011; Zatsiorsky i Kreamer, 2006):

$$
\text { Bilateralno }-\mathrm{RFD}_{\mathrm{Fmax}}=\mathrm{F}_{\text {max }} / \mathrm{tF}_{\text {max }}
$$

Dominantna noga $-\mathrm{RFD}_{\mathrm{FmaxDO}}=\mathrm{F}_{\operatorname{maxDO}} / \mathrm{tF}_{\operatorname{maxDO}}$

Nedominantna noga $-\mathrm{RFD}_{\mathrm{FmaxND}}=\mathrm{F}_{\operatorname{maxND}} / \mathrm{tF}_{\operatorname{maxND}}$

Gde: $\mathrm{F}_{\max }, \mathrm{F}_{\max D O}, \mathrm{~F}_{\operatorname{maxND}}$ predstavljaju maksimalnu vrednost dostignute izometrijske sile opružača nogu bilateralno i unilateralno (dominantne i nedominantne noge), dok $\mathrm{tF}_{\text {max }}, \mathrm{tF}_{\text {maxDO }}$, $\mathrm{tF}_{\operatorname{maxND}}$ predstavljaju vreme u s potrebno da se dostigne maksimalna sila bilateralno i unilateralno (dominantne i nedominantne noge), izraženo $\mathrm{u} \mathrm{N} \cdot \mathrm{s}^{-1}$.

- Pokazatelj razvijenosti specifičnog nivoa eksplozivne sile tj. eksplozivnosti opružača nogu bilateralno i unilateralno (dominantne i nedominantne noge), ili $\mathrm{S}$ gradijent, izmjeren na $50 \%$ od $\mathrm{F}_{\max }$ je dobijen na osnovu slijedeće procedure (Ibid):

Bilateralno $-\mathrm{RFD}_{50 \%}=\mathrm{F}_{50 \%} / \mathrm{tF}_{50 \%}$

Dominantna noga - RFD ${ }_{50 \% \text { DO }}=\mathrm{F}_{50 \% \mathrm{DO}} / \mathrm{tF}_{50 \% \mathrm{DO}}$

Nedominantna noga $-\mathrm{RFD}_{50 \% \mathrm{ND}}=\mathrm{F}_{50 \% \mathrm{ND}} / \mathrm{tF}_{50 \% \mathrm{ND}}$
Gde: $\mathrm{F}_{50 \%}, \mathrm{~F}_{50 \% \mathrm{DO}}$ i $\mathrm{F}_{50 \% \mathrm{ND}}$ predstavljaju vrijednosti izometrijske sile opružača nogu bilateralno i unilateralno (dominantne i nedominantne noge) dostignute na $50 \%$ od $\mathrm{F}_{\text {max }}$, dok $\mathrm{tF}_{50 \%}, \mathrm{tF}_{50 \% \mathrm{DO}} \mathrm{i}$ $\mathrm{tF}_{50 \% \mathrm{ND}}$ predstavljaju vremena u s potrebna za dostizanje $\mathrm{F}_{50 \%}, \mathrm{~F}_{50 \% \mathrm{DO}}$ i $\mathrm{F}_{50 \% \mathrm{ND}}$, izraženo u $\mathrm{N} \cdot \mathrm{s}^{-1}$.

- Pokazatelj specijalnog nivoa razvijenosti eksplozivne sile tj. eksplozivnosti opružača nogu bilateralno i unilateralno (dominantne i nedominantne noge), izmjeren na $250 \mathrm{~ms}$ od $\mathrm{tF}_{\text {max }}$ je dobijen na osnovu slijedeće procedure (Ibid):

Bilateralno $-\mathrm{RFD}_{250 \mathrm{~ms}}=\mathrm{F}_{250 \mathrm{~ms}} / \mathrm{tF}_{250 \mathrm{~ms}}$
Dominantna noga $-\mathrm{RFD}_{250 \mathrm{msDO}}=\mathrm{F}_{250 \mathrm{msDO}} / \mathrm{tF}_{250 \mathrm{msDO}}$
Nedominantna noga $-\mathrm{RFD}_{250 \mathrm{msND}}=\mathrm{F}_{250 \mathrm{msND}} / \mathrm{tF}_{250 \mathrm{msND}}$

Gde: $F_{250 \mathrm{~ms}}, F_{250 \mathrm{msDO}}$ i $\mathrm{F}_{250 \mathrm{msND}}$ predstavljaju vrijednosti izometrijske sile opružača nogu bilateralno i unilateralno (dominantne i nedominantne noge), dostignute na $250 \mathrm{~ms}$ od $\mathrm{tF}_{\text {max }}$, dok $\mathrm{tF}_{250 \mathrm{~ms}}$, $\mathrm{tF}_{250 \mathrm{msDO}} \mathrm{i} \mathrm{tF}_{250 \mathrm{msND}}$ predstavljaju vremena u s potrebno za dostizanje izometrijske sile opružača nogu bilateralno i unilateralno (dominantne $i$ nedominantne noge) izmjerene na $250 \mathrm{~ms}$, izraženo u $\mathrm{N} \bullet \mathrm{s}^{-1}$.

- Pokazatelj specijalnog nivoa razvijenosti eksplozivne sile tj. eksplozivnosti opružača nogu bilateralno i unilateralno (dominantne i nedominantne noge), izmjeren na $180 \mathrm{~ms}$ od $\mathrm{tF}_{\text {max }}$ je dobijen na osnovu slijedeće procedure (Ibid):

Bilateralno $-\mathrm{RFD}_{180 \mathrm{~ms}}=\left(\mathrm{F}_{180 \mathrm{~ms}} / \mathrm{tF}_{180 \mathrm{~m}}\right)$ Dominantna noga $-\mathrm{RFD}_{180 \mathrm{msDO}}=\mathrm{F}_{180 \mathrm{msDO}} / \mathrm{tF}_{180 \mathrm{msDO}}$ Nedominantna noga $-\mathrm{RFD}_{180 \mathrm{msND}}=\mathrm{F}_{180 \mathrm{msND}} / \mathrm{tF}_{180 \mathrm{msND}}$

Gde: $\mathrm{F}_{180 \mathrm{~ms}}, \mathrm{~F}_{180 \mathrm{~ms} \mathrm{DO}}$ i $\mathrm{F}_{180 \mathrm{msND}}$ predstavljaju vrijednosti izometrijske sile opružača nogu bilateralno i unilateralno (dominantne i nedominantne noge) dostignute na $180 \mathrm{~ms}$ od $\mathrm{tF}_{\text {max }}$, dok $\mathrm{tF}_{180 \mathrm{~ms}}$, $\mathrm{tF}_{180 \mathrm{msDO}} \mathrm{i} \mathrm{tF}_{180 \mathrm{msND}}$ predstavljaju vrijeme u s potrebno za dostizanje izometrijske sile opružača nogu bilateralno i unilateralno (dominantne i nedominantne noge) izmerene na $180 \mathrm{~ms}$, izraženo $\mathrm{u} N \cdot \mathrm{s}^{-1}$.

- Pokazatelj specijalnog nivoa razvijenosti eksplozivne sile tj. eksplozivnosti opružača nogu bilateralno i unilateralno (dominantne i nedominantne noge), izmjeren na $100 \mathrm{~ms}$ od $\mathrm{tF}_{\text {max }}$ je dobijen na osnovu slijedeće procedure (Ibid):

Bilateralno $-\mathrm{RFD}_{100 \mathrm{~ms}}=\mathrm{F}_{100 \mathrm{~ms}} / \mathrm{tF}_{100 \mathrm{~ms}}$
Dominantna noga $-\mathrm{RFD}_{100 \mathrm{msDO}}=\mathrm{F}_{100 \mathrm{msDO}} / \mathrm{tF}_{100 \mathrm{msDO}}$
Nedominantna noga $-\mathrm{RFD}_{100 \mathrm{msND}}=\mathrm{F}_{100 \mathrm{msND}} / \mathrm{tF}_{100 \mathrm{msND}}$

Gde: $F_{100 \mathrm{~ms}}, F_{100 \mathrm{msDO}}$ i F100 ${ }_{\mathrm{msND}}$ predstavljaju vrijednosti izometrijske sile opružača nogu bi- 
lateralno i unilateralno (dominantne i nedominantne noge), dostignute na $100 \mathrm{~ms}$ od $\mathrm{tF}_{\text {max }}$, dok $\mathrm{tF}_{100 \mathrm{~ms}}, \mathrm{tF}_{100 \mathrm{msDO}} \mathrm{i} \mathrm{tF}_{100 \mathrm{msND}}$ predstavljaju vrijeme u s potrebno za dostizanje izometrijske sile opružača nogu bilateralno i unilateralno (dominantne i nedominantne noge) izmjerene na $100 \mathrm{~ms}$, izraženo u $\mathrm{N} \cdot \mathrm{s}^{-1}$.

\section{Postupak merenja}

Za procenu kontraktilnih karakteristika izometrijske mišićne sile opružača nogu (bilateralno i unilateralno) korišćena je standardizovana oprema, sprava metalne konstrukcije gde je sila merena u sedećem položaju. Testiranje i akvizicija sirovih podataka je

\section{SLIKA 1}

Aparatura za merenje maksimalne iz̧ometrijske sile opružača nogu (a), tenżiometrijska sonda unutar platforme za stopala (b), čitač sile s računarom (c).
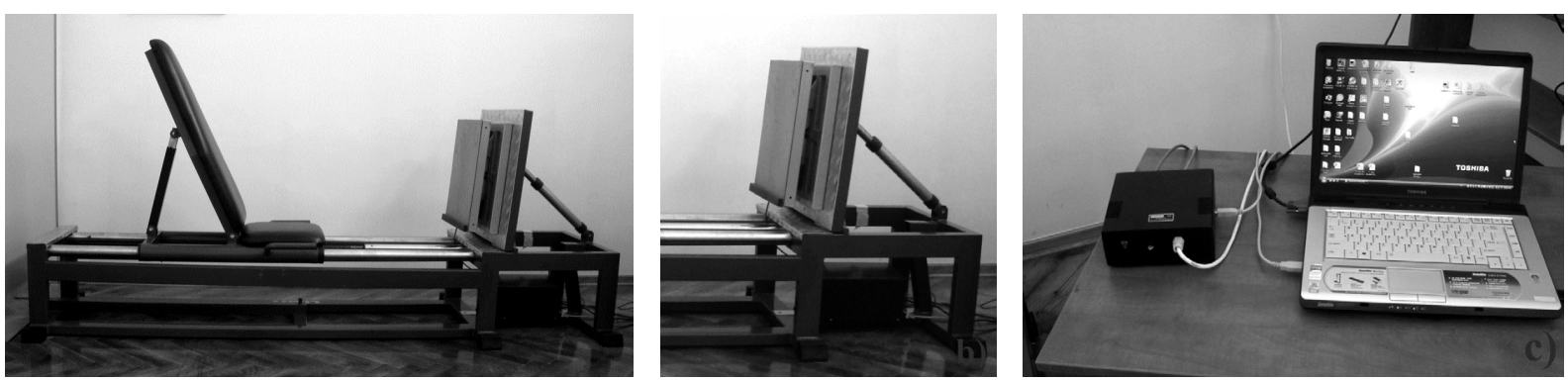

\section{SLIKA 2}

Položaj ispitanika tokom merenja.

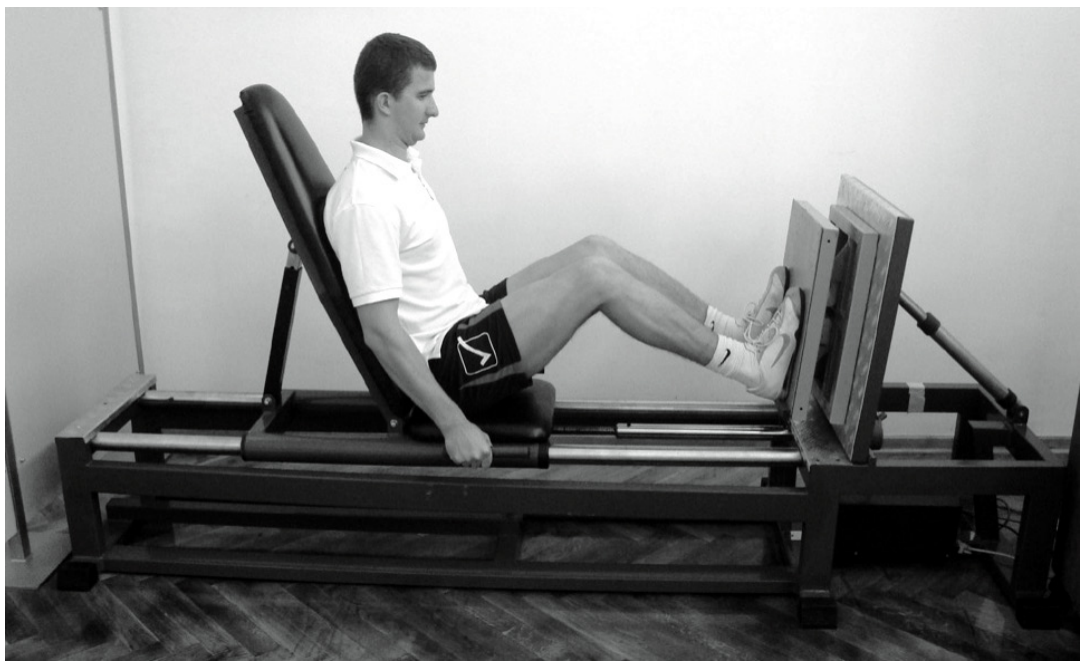

realizovano korišćenjem posebno izrađenog hardversko-softverskog sistema, M_S_NI CW UI 8.0, od strane Instituta „Nikola Tesla“, Beograd za potrebe kontrole i praćenja treniranosti sportista u Zavodu za sport i medicinu sporta RS (Dopsaj i Ivanović, 2011) (Slika 1).

Tenziometrijska sonda, frekvencije odabira, uzorkovanja podataka od $2000 \mathrm{~Hz}$, nalazi se unutar platforme za stopala koja je fiksirana za konstrukciju (National Instruments, Austin, TX, USA). Tenziometrijska sonda, granične frekvencije NF filtra kroz koji se propušta izmjereni signal od $50 \mathrm{~Hz}$, bila je povezana $\mathrm{s}$ čitačem sile (indikatorom sile) povezanim s računarom.

$\mathrm{Na}$ osnovu upotrebljenog protokola testiranja, ispitanici su tokom testa mjerenja karakteristika F-t krive opružača nogu bilateralno i unilateralno realizovali po dva pojedinačna testovna pokušaja, prema slijedećoj proceduri: svi ispitanici su testirani posle 5 minuta individualnog zagrevanja. Zadatak ispitanika bio je da ostvare maksimalnu mišićnu silu primjenom maksimalno intenzivnog naprezanja u što kraćem vremenskom periodu u sjedećem položaju (pozicija guranja nogama). Testiranje je realizovano u izometrijskim uslovima naprezanja i pri uglu natkolenice i potkolenice od $120^{\circ}$, odnosno pri uglu potkoljenice i stopala od $90^{\circ}$ (Slika 2). Ispitanik je izvodio testovni pokušaj na zvučni signal mjerioca. Svaki ispitanik imao je pravo na dva pokušaja bilateralnog naprezanja i po dva pokušaja unilateralnog naprezanja (desna-lijevadesna-lijeva noga) između kojih je bila pauza od 
jednog minuta. Rezultati testa su automatski, pomoću korišćenja tenziometrijske sonde i pripadajućeg hardversko-softverskog sistema beleženi u posebnu bazu podataka uz mogućnost pregleda zapisa $F$ - $t$ krive (Slika 3). Za potrebe ovog rada analiziran je pokušaj sa izmjerenim najvećim pokazateljem opšteg ili bazičnog nivoa razvijenosti eksplozivne sile tj. eksplozivnosti opružača nogu.

\section{Statistička analiza}

Od statističkih metoda, pored deskriptivnog statističkog modela, za definisanje strukture, tj. stvarne

\section{SLIKA 3}

Zapis F-t krive.

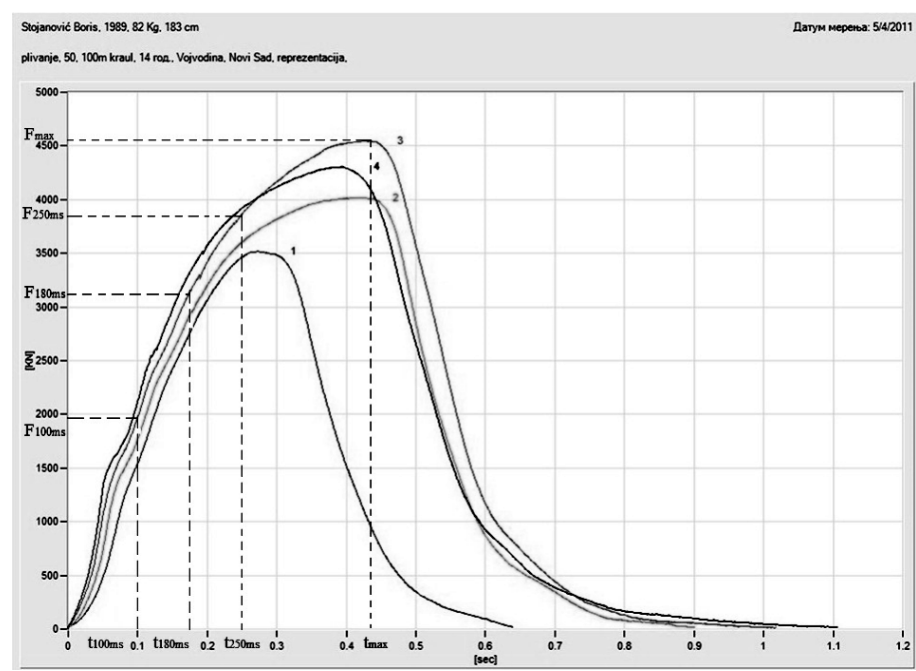

kvalitativne relacije između varijabli korišćena je multivarijaciona analiza iz grupe metoda međusobne zavisnosti. Od metoda međusobne zavisnosti upotrebljen je metod konfirmativne faktorske analize korišćenjem rotacija optimalne zavisnosti (Oblimin).

Procjena multivarijatne adekvatnosti sirovih podataka vršen je primenom mjere KMO (KaiserMeyer-Olkin measure of sampling adequacy i Bartletovim testom sferičnosti - Bartlett's Tests of Sphericity) čija je statistička značajnost izražena preko hi kvadrata ( $\chi^{2}$ ) (Hair, Rolph, Ronald i William, 1998).

\section{REZULTATI}

Na Tabeli 2 su prikazani rezultati adekvatnosti datog uzorka analiziranih varijabli subuzoraka ispitanika muškog pola.

$\mathrm{Na}$ Tabeli 3 su prikazani izdvojeni faktori sa strukturnim pokazateljima objašnjene varijanse uzorka svih posmatranih varijabli.

Mera KMO pokazuje visoku statistički značajnu vrednost multivarijatne adekvatnosti datih varijabli za ispitanike grupe brzinsko-snažnih sportova na nivou od 0,806 , tj. 80,6\%, dok vrednost $\chi^{2}$ testa iznosi 1229,941 , na nivou $p=0,000$; za ispitanike grupe

\section{TABELA 2}

Mjera adekvatnosti faktorizovanog u₹orka ispitanika muskeog pola.

\begin{tabular}{lrrrrr}
\hline Kaiser-Meyer-Olkin mjera & & 1 & 2 & \multicolumn{1}{c}{3} & \multicolumn{1}{c}{4} \\
\cline { 2 - 6 } adekvatnosti & & 0,806 & 0,802 & 0,737 & 0,680 \\
\hline \multirow{3}{*}{ Bartlett test sferičnosti } & $\chi^{2}$ & 1229,941 & 2804,331 & 1760,349 & 913,941 \\
\cline { 2 - 6 } & $d f$ & 105 & 105 & 105 & 105 \\
\cline { 2 - 6 } & $p$ & $\mathbf{0 , 0 0 0}$ & $\mathbf{0 , 0 0 0}$ & $\mathbf{0 , 0 0 0}$ & $\mathbf{0 , 0 0 0}$ \\
\hline
\end{tabular}

Legenda: 1 - Brzinsko-snažni sportovi; 2 - Sportovi sa kompleksnim ispoljavanjem svih motoričkih svojstava; 3 - Sportovi izdržljivosti; 4 - Kontrolna grupa; $\chi^{2}$ - Hi-kvadrat test; $d f$ - Stepeni slobode; $p$ - Vjerovatnoća. 
TABELA 3

Izdvojeni faktori sa strukturnim pokazateljima objašnjene varijanse.

\begin{tabular}{|c|c|c|c|}
\hline \multirow{2}{*}{ Komponente } & \multicolumn{3}{|c|}{ Suma kvadrata opterećenja } \\
\hline & Ukupno & $\%$ varijanse & Kumulativno \% \\
\hline \multicolumn{4}{|c|}{ Brzinsko-snažni sportovi } \\
\hline 1 & 10,413 & 69,418 & 69,418 \\
\hline 2 & 1,699 & 11,329 & 80,748 \\
\hline 3 & 1,073 & 7,152 & 87,899 \\
\hline \multicolumn{4}{|c|}{ Sportovi sa kompleksnim ispoljavanjem svih motoričkih svojstava } \\
\hline 1 & 9,193 & 61,285 & 61,285 \\
\hline 2 & 1,979 & 13,191 & 74,476 \\
\hline 3 & 1,256 & 8,376 & 82,852 \\
\hline 4 & 1,210 & 8,067 & 90,919 \\
\hline \multicolumn{4}{|c|}{ Sportovi izdržljivosti } \\
\hline 1 & 9,066 & 60,438 & 60,438 \\
\hline 2 & 2,148 & 14,317 & 74,755 \\
\hline 3 & 1,517 & 10,112 & 84,866 \\
\hline 4 & 1,022 & 6,815 & 91,682 \\
\hline \multicolumn{4}{|c|}{ Kontrolna grupa } \\
\hline 1 & 8,934 & 59,560 & 59,560 \\
\hline 2 & 2,718 & 18,120 & 77,679 \\
\hline 3 & 1,423 & 9,487 & 87,166 \\
\hline
\end{tabular}

sportova sa kompleksnim ispoljavanjem svih motoričkih svojstava na nivou od 0,802, tj. $80,2 \%$, dok vrednost $\chi^{2}$ testa iznosi 2804,331, na nivou $p=0,000$; za ispitanike grupe sportova izdržljivosti na nivou od 0,737 , tj. $73,7 \%$, dok vrednost $\chi^{2}$ testa iznosi 1760,349 , na nivou $p=0,000$; za ispitanike kontrolne grupe na nivou od 0,680 , tj. $68,0 \%$, dok vrednost $\chi^{2}$ testa iznosi 913,941 , na nivou $p=0,000$.

To praktično znači da se izmereni podaci sami po sebi validno mogu iskoristiti na nivou od 68,0\% (kontrolna grupa) do 80,6\% (brzinsko-snažni sportovi), što ukazuje na činjenicu da ostatak varijabiliteta u iznosu od 32,0\% (kontrolna grupa) do 19,4\% (brzinskosnažni sportovi) nema validnu adekvatnost i predstavlja izvor šuma, odnosno pripada varijabilitetu koji se generalno može pripisati prostoru koji ne pripada datom merenju (npr. različite sistemske ili slučajne greške nastale tokom merenja, prostor različite motivacije ispitanika za testiranje, prostor različitog nivoa utreniranosti ispitanika, itd...).

$\mathrm{Na}$ Tabeli 4 je data matrica strukture sa saturacijom varijabli u funkciji izdvojenih faktora.

Faktorska analiza je nad datim varijablama izdvojila tri faktora za ispitanike grupe brzinsko-snažnih sportova i kontrolne grupe, a četiri faktora za ispitanike grupe sportova sa kompleksnim ispoljavanjem svih motoričkih svojstava i sportova izdržljivosti (Tabele 2, 3), koji su ukupno kumulativno objasnili $87,899 \%$ valjane varijanse za ispitanike grupe brzinskosnažnih sportova; $89,380 \%$ za ispitanike grupe sportova sa kompleksnim ispoljavanjem svih motoričkih svojstava; $91,682 \%$ za ispitanike sportova izdržljivosti; $87.166 \%$ za ispitanike kontrolne grupe.

Kod brzinsko-snažne grupe sportova $80,6 \%$ izmerenog prostora, koji je činio set sastavljen od 15 varijabli je definisalo 3 faktora, sa veoma visoko objašnjenim specificitetom $i$ to na nivou od $87,899 \%$ objašnjene zajedničke varijanse.

Kod sportova sa kompleksnim ispoljavanjem svih motoričkih svojstava 80,2\% izmjerenog prostora, koji je činio set sastavljen od 15 varijabli je definisalo 4 faktora, sa veoma visoko objašnjenim specificitetom, $i$ to na nivou od $90,919 \%$ objašnjene zajedničke varijanse.

Kod sportova izdržljivosti $73,7 \%$ izmjerenog prostora, koji je činio set sastavljen od 15 varijabli je definisao 4 faktora, sa veoma visoko objašnjenim specificitetom, i to na nivou od $91,682 \%$ objašnjene zajedničke varijanse.

Kod kontrolne grupe 68,0\% izmjerenog prostora, koji je činio set sastavljen od 15 varijabli je definisalo 3 faktora, sa veoma visoko objašnjenim specificitetom, 


\section{TABELA 4}

Matrica strukture kod ispitanika muškog pola.

\begin{tabular}{|c|c|c|c|c|c|c|c|c|}
\hline \multirow{9}{*}{ 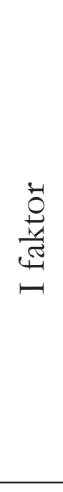 } & \multicolumn{2}{|c|}{ Speed-strength } & \multicolumn{2}{|c|}{ Complex } & \multicolumn{2}{|c|}{ Endurance } & \multicolumn{2}{|l|}{ Control } \\
\hline & $\mathrm{RFD}_{180 \mathrm{msND}}$ & 0,957 & $\mathrm{RFD}_{180 \mathrm{msND}}$ & 0,988 & $\mathrm{RFD}_{180 \mathrm{msND}}$ & 0,984 & $\mathrm{RFD}_{100 \mathrm{~ms} \mathrm{ND}}$ & 0,968 \\
\hline & $\mathrm{RFD}_{50 \% \mathrm{ND}}$ & 0,957 & $\mathrm{RFD}_{50 \% \mathrm{ND}}$ & 0,986 & $\mathrm{RFD}_{50 \% \mathrm{ND}}$ & 0,966 & $\mathrm{RFD}_{50 \% \mathrm{DO}}$ & 0,961 \\
\hline & $\mathrm{RFD}_{250 \mathrm{msND}}$ & 0,923 & $\mathrm{RFD}_{100 \mathrm{msND}}$ & 0,926 & $\mathrm{RFD}_{250 \mathrm{msND}}$ & 0,937 & $\mathrm{RFD}_{50 \% \mathrm{ND}}$ & 0,958 \\
\hline & $\mathrm{RFD}_{100 \mathrm{msND}}$ & 0,872 & $\mathrm{RFD}_{250 \mathrm{msND}}$ & 0,918 & $\mathrm{RFD}_{100 \mathrm{msND}}$ & 0,878 & $\mathrm{RFD}_{180 \mathrm{~ms} \mathrm{DO}}$ & 0,946 \\
\hline & $\mathrm{RFD}_{180 \mathrm{~ms}}$ & 0,847 & & & & & $\mathrm{RFD}_{180 \mathrm{msND}}$ & 0,946 \\
\hline & $\mathrm{RFD}_{50 \%}$ & 0,847 & & & & & $\mathrm{RFD}_{10 \mathrm{msDO}}$ & 0,944 \\
\hline & $\mathrm{RFD}_{250}$ & 0,831 & & & & & $\mathrm{RFD}_{250 \mathrm{msDO}}$ & 0,942 \\
\hline & $\mathrm{RFD}_{100}$ & 0,782 & & & & & $\mathrm{RFD}_{250 \mathrm{msND}}$ & 0,885 \\
\hline \multirow{5}{*}{ 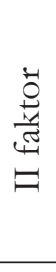 } & \multicolumn{2}{|c|}{ Speed-strength } & \multicolumn{2}{|c|}{ Complex } & \multicolumn{2}{|c|}{ Endurance } & \multicolumn{2}{|l|}{ Control } \\
\hline & $\mathrm{RFD}_{\text {Fmax }}$ & 0,903 & $\mathrm{RFD}_{\text {FmaxDO }}$ & 0,897 & $\mathrm{RFD}_{180 \mathrm{~ms}}$ & 0,991 & $\mathrm{RFD}_{180 \mathrm{~ms}}$ & 0,991 \\
\hline & $\mathrm{RFD}_{\mathrm{FmaxND}}$ & 0,866 & $\mathrm{RFD}_{\text {FmaxND }}$ & 0,874 & $\mathrm{RFD}_{50 \%}$ & 0,982 & $\mathrm{RFD}_{50 \%}$ & 0,984 \\
\hline & $\mathrm{RFD}_{\text {FmaxDO }}$ & 0,782 & $\mathrm{RFD}_{\mathrm{Fmax}}$ & 0,821 & $\mathrm{RFD}_{250 \mathrm{~ms}}$ & 0,938 & $\mathrm{RFD}_{250 \mathrm{~ms}}$ & 0,947 \\
\hline & & & & & $\mathrm{RFD}_{100 \mathrm{~ms}}$ & 0,924 & $\mathrm{RFD}_{100 \mathrm{~ms}}$ & 0,887 \\
\hline \multirow{5}{*}{ 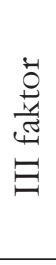 } & \multicolumn{2}{|c|}{ Speed-strength } & \multicolumn{2}{|c|}{ Complex } & \multicolumn{2}{|c|}{ Endurance } & \multicolumn{2}{|l|}{ Control } \\
\hline & $\mathrm{RFD}_{180 \mathrm{msDO}}$ & 0,989 & $\mathrm{RFD}_{180 \mathrm{msDO}}$ & 0,981 & $\mathrm{RFD}_{\text {FmaxDo }}$ & 0,943 & $\mathrm{RFD}_{\text {Fmax }}$ & 0,923 \\
\hline & $\mathrm{RFD}_{50 \% \mathrm{DO}}$ & 0,980 & $\mathrm{RFD}_{50 \% \mathrm{DO}}$ & 0,980 & $\mathrm{RFD}_{\mathrm{FmaxND}}$ & 0,926 & $\mathrm{RFD}_{\text {FmaxND }}$ & 0,879 \\
\hline & $\mathrm{RFD}_{100 \mathrm{msDO}}$ & 0,956 & $\mathrm{RFD}_{100 \mathrm{msDO}}$ & 0,943 & $\mathrm{RFD}_{\mathrm{Fmax}}$ & 0,853 & $\mathrm{RFD}_{\mathrm{FmaxDO}}$ & 0,636 \\
\hline & $\mathrm{RFD}_{250 \mathrm{msDO}}$ & 0,946 & $\mathrm{RFD}_{250 \mathrm{msDO}}$ & 0,888 & & & & \\
\hline \multirow{5}{*}{ 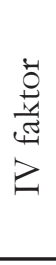 } & \multicolumn{2}{|c|}{ Speed-strength } & \multicolumn{2}{|c|}{ Complex } & \multicolumn{2}{|c|}{ Endurance } & \multicolumn{2}{|l|}{ Control } \\
\hline & & & $\mathrm{RFD}_{180 \mathrm{~ms}}$ & $-0,988$ & $\mathrm{RFD}_{180 \mathrm{~ms}}$ & $-0,980$ & & \\
\hline & & & $\mathrm{RFD}_{50 \%}$ & $-0,983$ & $\mathrm{RFD}_{50 \% \mathrm{DO}}$ & $-0,973$ & & \\
\hline & & & $\mathrm{RFD}_{100 \mathrm{~ms}}$ & $-0,946$ & $\mathrm{RFD}_{100 \mathrm{msDO}}$ & $-0,962$ & & \\
\hline & & & $\mathrm{RFD}_{250 \mathrm{~ms}}$ & $-0,936$ & $\mathrm{RFD}_{250 \mathrm{msDO}}$ & $-0,888$ & & \\
\hline
\end{tabular}

Legenda: $\mathbf{R F D}_{\mathrm{DO}}$ - Dominantana noga; $\mathbf{R F D}_{\mathrm{ND}}$ - Nedominantna noga; Speed-strength - Brzinsko-snažni sportovi; Complex - Sportovi sa kompleksnim ispoljavanjem svih motoričkih svojstava; Endurance - Sportovi izdržljivosti; Control - Kontrolna grupa.

\section{TABELA 5}

Mera adekvatnosti faktorizovanog uzorka ispitanika ženskog pola.

\begin{tabular}{lrrrrr}
\hline $\begin{array}{l}\text { Kaiser-Meyer-Olkin mjera } \\
\text { adekvatnosti }\end{array}$ & \multicolumn{1}{c}{2} & \multicolumn{1}{c}{3} & \multicolumn{1}{c}{4} \\
\cline { 2 - 6 } & & 0,715 & 0,788 & 0,809 & 0,718 \\
\hline \multirow{3}{*}{ Bartlett test sferičnosti } & $\chi^{2}$ & 831,927 & 1300,777 & 1042,572 & 827,770 \\
\cline { 2 - 6 } & $d f$ & 105 & 105 & 105 & 105 \\
\cline { 2 - 6 } & $p$ & $\mathbf{0 , 0 0 0}$ & $\mathbf{0 , 0 0 0}$ & $\mathbf{0 , 0 0 0}$ & $\mathbf{0 , 0 0 0}$ \\
\hline
\end{tabular}

Legenda: 1 - Brzinsko-snažni sportovi; 2 - Sportovi sa kompleksnim ispoljavanjem svih motoričkih svojstava; 3 - Sportovi izdržljivosti; 4 - Kontrolna grupa; $\chi^{2}$ - Hi-kvadrat test; $d f$ - Stepeni slobode; $p$ - Vjerovatnoća. 
i to na nivou od $87,166 \%$ objašnjene zajedničke varijanse.

Na Tabeli 5 su prikazani rezultati adekvatnosti datog uzorka analiziranih varijabli subuzoraka ispitanika ženskog pola.

$\mathrm{Na}$ Tabeli 6 su prikazani izdvojeni faktori sa strukturnim pokazateljima objašnjene varijanse uzorka svih posmatranih varijabli.

Mera KMO pokazuje visoku statistički značajnu vrijednost multivarijatne adekvatnosti datih varijabli za ispitanike grupe brzinsko-snažnih sportova na nivou od 0,715 , tj. $71,5 \%$, dok vrednost $\chi^{2}$ testa iznosi 831,927 , nivou $p=0,000$; za ispitanike grupe sportova sa kompleksnim ispoljavanjem svih motoričkih svojstava na nivou od 0,788 , tj. $78,8 \%$, dok vrijednost $\chi^{2}$ testa iznosi 1300,777 , na nivou $p=0,000$; za ispitanike grupe sportova izdržljivosti na nivou od 0,809 , tj. $80,9 \%$, dok vrijednost $\chi^{2}$ testa iznosi 1042,572 , na nivou $p=0,000$; za ispitanike kontrolne grupe na nivou od 0,718 , tj. $71,8 \%$, dok vrijednost $\chi^{2}$ testa iznosi 827,770 , na nivou $p=0,000$.

To praktično znači da se izmereni podaci sami po sebi validno mogu iskoristiti na nivou od $71,5 \%$ (brzinsko-snažna grupa sportova) do $80,9 \%$ (sportovi izdržljivosti), što ukazuje na činjenicu da ostatak varijabiliteta u iznosu od 28,5\% (brzinsko-snažna grupa sportova) do 19,1\% (sportovi izdržljivosti) nema validnu adekvatnost i predstavlja izvor šuma, odnosno pripada varijabilitetu koji se generalno može pripisati prostoru koji ne pripada datom mjerenju (npr. različite sistemske ili slučajne greške nastale tokom mjerenja, prostor različite motivacije ispitanika za testiranje, prostor različitog nivoa utreniranosti ispitanika, itd...).

Faktorska analiza je nad datim varijablama izdvojila četiri faktora za ispitanike grupe brzinsko-snažnih sportova $i$ kontrolne grupe, a po tri faktora za ispitanike grupe sportova sa kompleksnim ispoljavanjem svih motoričkih svojstava i sportova izdržljivosti (Tabele 5, 6), koji su ukupno kumulativno objasnili $91,689 \%$ valjane varijanse za ispitanike grupe brzinskosnažnih sportova; $86,604 \%$ za ispitanike grupe sportova sa kompleksnim ispoljavanjem svih motoričkih svojstava; $87,871 \%$ za ispitanike sportova izdržljivosti; $91,235 \%$ za ispitanike kontrolne grupe.

$\mathrm{Na}$ Tabeli 7 data je matrica strukture sa saturacijom varijabli u funkciji izdvojenih faktora.

Kod brzinsko-snažne grupe sportova 71,5\% izmjerenog prostora, koji je činio set sastavljen od 15 varijabli je definisalo 4 faktora, sa veoma visoko objašnjenim specificitetom, i to na nivou od $91,689 \%$ objašnjene zajedničke varijanse.

\section{TABELA 6}

Abstracted factors with the structure indicators of the explained variance.

\begin{tabular}{cccc}
\hline \multirow{2}{*}{ Komponente } & \multicolumn{3}{c}{ Suma kvadrata opterećenja } \\
\cline { 2 - 4 } & Ukupno & \% varianse & Kumulativni \% \\
\hline \multicolumn{4}{c}{ Brzinsko-snažni sportovi } \\
\hline 2 & 8,141 & 54,276 & 54,276 \\
\hline 3 & 2,644 & 17,628 & 71,904 \\
\hline 4 & 1,908 & 12,723 & 84,627 \\
\hline Sportovi sa kompleksnim ispoljavanjem svih motoričkih svojstava \\
\hline 1 & 1,059 & 7,062 & 67,742 \\
\hline 2 & 10,161 & 67,742 & 78,776 \\
\hline 3 & 1,655 & 11,034 \\
\hline \multicolumn{4}{c}{7,828} \\
\hline 1 & 1,174 & 86,604 \\
\hline 2 & Sportovi izdržljivosti \\
\hline 3 & 10,210 & 68,067 & 68,067 \\
\hline \multicolumn{4}{c}{}
\end{tabular}


TABELA 7

Matrica strukture kod ispitanika ženskog pola.

\begin{tabular}{|c|c|c|c|c|c|c|c|c|}
\hline \multirow{9}{*}{ 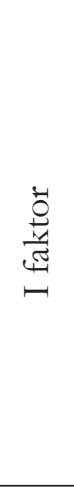 } & \multicolumn{2}{|c|}{ Speed-strength } & \multicolumn{2}{|c|}{ Complex } & \multicolumn{2}{|c|}{ Endurance } & \multicolumn{2}{|c|}{ Control } \\
\hline & $\mathrm{RFD}_{180 \mathrm{msND}}$ & 0,993 & $\mathrm{RFD}_{180 \mathrm{msND}}$ & 0,959 & $\mathrm{RFD}_{180 \mathrm{msND}}$ & 0,959 & $\mathrm{RFD}_{180 \mathrm{msND}}$ & 0,961 \\
\hline & $\mathrm{RFD}_{50 \% \mathrm{ND}}$ & 0,966 & $\mathrm{RFD}_{50 \% \mathrm{ND}}$ & 0,948 & $\mathrm{RFD}_{250 \mathrm{msND}}$ & 0,932 & $\mathrm{RFD}_{50 \% \mathrm{ND}}$ & 0,947 \\
\hline & $\mathrm{RFD}_{100 \mathrm{msND}}$ & 0,915 & $\mathrm{RFD}_{250 \mathrm{msND}}$ & 0,940 & $\mathrm{RFD}_{180 \mathrm{msDO}}$ & 0,928 & $\mathrm{RFD}_{250 \mathrm{~ms} \mathrm{DD}}$ & 0,929 \\
\hline & $\mathrm{RFD}_{250 \mathrm{msND}}$ & 0,893 & $\mathrm{RFD}_{100 \mathrm{msND}}$ & 0,882 & $\mathrm{RFD}_{50 \% \mathrm{ND}}$ & 0,926 & $\mathrm{RFD}_{100 \mathrm{msND}}$ & 0,920 \\
\hline & & & $\mathrm{RFD}_{\mathrm{FmaxND}}$ & 0,816 & $\mathrm{RFD}_{50 \% \mathrm{DO}}$ & 0,916 & $\mathrm{RFD}_{250 \mathrm{msDO}}$ & 0,917 \\
\hline & & & $\mathrm{RFD}_{\mathrm{FmaxDO}}$ & 0,707 & $\mathrm{RFD}_{100 \mathrm{msND}}$ & 0,908 & $\mathrm{RFD}_{180 \mathrm{msDO}}$ & 0,888 \\
\hline & & & $\mathrm{RFD}_{\text {Fmax }}$ & 0,672 & $\mathrm{RFD}_{250 \mathrm{msDO}}$ & 0,899 & $\mathrm{RFD}_{50 \% \mathrm{DO}}$ & 0,869 \\
\hline & & & & & $\mathrm{RFD}_{100 \mathrm{msDO}}$ & 0,886 & $\mathrm{RFD}_{100 \mathrm{msDO}}$ & 0,783 \\
\hline \multirow{5}{*}{$\begin{array}{l}\frac{\overrightarrow{0}}{\tilde{I}} \\
ت \\
ت\end{array}$} & \multicolumn{2}{|c|}{ Speed-strength } & \multicolumn{2}{|c|}{ Complex } & \multicolumn{2}{|c|}{ Endurance } & \multicolumn{2}{|c|}{ Control } \\
\hline & $\mathrm{RFD}_{180 \mathrm{~ms}}$ & $-0,978$ & $\mathrm{RFD}_{50 \%}$ & 0,969 & $\mathrm{RFD}_{180 \mathrm{~ms}}$ & $-0,990$ & $\mathrm{RFD}_{180 \mathrm{~ms}}$ & 0,992 \\
\hline & $\mathrm{RFD}_{50 \%}$ & $-0,948$ & $\mathrm{RFD}_{180 \mathrm{~ms}}$ & 0,954 & $\mathrm{RFD}_{50 \%}$ & $-0,989$ & $\mathrm{RFD}_{50 \%}$ & 0,977 \\
\hline & $\mathrm{RFD}_{100 \mathrm{~ms}}$ & $-0,945$ & $\mathrm{RFD}_{100 \mathrm{~ms}}$ & 0,936 & $\mathrm{RFD}_{250 \mathrm{~ms}}$ & $-0,971$ & $\mathrm{RFD}_{250 \mathrm{~ms}}$ & 0,965 \\
\hline & $\mathrm{RFD}_{250 \mathrm{~ms}}$ & $-0,876$ & $\mathrm{RFD}_{250 \mathrm{~ms}}$ & 0,869 & $\mathrm{RFD}_{100 \mathrm{~ms}}$ & $-0,069$ & $\mathrm{RFD}_{100 \mathrm{~ms}}$ & 0,945 \\
\hline \multirow{5}{*}{ 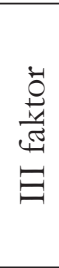 } & \multicolumn{2}{|c|}{ Speed-strength } & \multicolumn{2}{|c|}{ Complex } & \multicolumn{2}{|c|}{ Endurance } & \multicolumn{2}{|c|}{ Control } \\
\hline & RFD $_{\text {FmaxDO }}$ & 0,938 & $\mathrm{RFD}_{180 \mathrm{msDO}}$ & $-0,995$ & $\mathrm{RFD}_{\mathrm{FmaxDO}}$ & 0,916 & $\mathrm{RFD}_{\text {FmaxDo }}$ & 0,919 \\
\hline & $\mathrm{RFD}_{\mathrm{FmaxND}}$ & 0,866 & $\mathrm{RFD}_{50 \% \mathrm{DO}}$ & $-0,994$ & $\mathrm{RFD}_{\mathrm{FmaxND}}$ & 0,807 & $\mathrm{RFD}_{\mathrm{FmaxND}}$ & 0,885 \\
\hline & $\mathrm{RFD}_{\text {Fmax }}$ & 0,857 & $\mathrm{RFD}_{250 \mathrm{msDO}}$ & $-0,978$ & $\mathrm{RFD}_{\mathrm{Fmax}}$ & 0,774 & & \\
\hline & & & $\mathrm{RFD}_{100 \mathrm{msDO}}$ & $-0,965$ & & & & \\
\hline \multirow{5}{*}{ 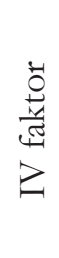 } & \multicolumn{2}{|c|}{ Speed-strength } & \multicolumn{2}{|c|}{ Complex } & \multicolumn{2}{|c|}{ Endurance } & \multicolumn{2}{|c|}{ Control } \\
\hline & $\mathrm{RFD}_{180 \mathrm{msDO}}$ & $-0,980$ & & & & & $\mathrm{RFD}_{\mathrm{Fmax}}$ & $-0,781$ \\
\hline & $\mathrm{RFD}_{250 \mathrm{msDO}}$ & $-0,962$ & & & & & & \\
\hline & $\mathrm{RFD}_{50 \% \mathrm{DO}}$ & $-0,894$ & & & & & & \\
\hline & $\mathrm{RFD}_{100 \mathrm{msDO}}$ & $-0,777$ & & & & & & \\
\hline
\end{tabular}

Legenda: $\mathbf{R F D}_{\mathrm{DO}}$ - Dominantana noga; $\mathbf{R F D}_{\mathrm{ND}}$ - Nedominantna noga; Speed-strength - Brzinsko-snažni sportovi; Complex - Sportovi sa kompleksnim ispoljavanjem svih motoričkih svojstava; Endurance - Sportovi izdržljivosti; Control - Kontrolna grupa.

Kod sportova sa kompleksnim ispoljavanjem svih motoričkih svojstava 78,8\% izmjerenog prostora, koji je činio set sastavljen od 15 varijabli je definisalo 3 faktora, sa veoma visoko objašnjenim specificitetom, i to na nivou od $86,604 \%$ objašnjene zajedničke varijanse (Tabela 6,7).

Kod sportova izdržljivosti 80,9\% izmjerenog prostora, koji je činio set sastavljen od 15 varijabli je definisalo 3 faktora, sa veoma visoko objašnjenim specificitetom, i to na nivou od $87,871 \%$ objašnjene zajedničke varijanse.

Kod kontrolne grupe 71,8\% izmjerenog prostora, koji je činio set sastavljen od 15 varijabli je definisalo 4 faktora, sa veoma visoko objašnjenim specificitetom, i to na nivou od $91,235 \%$ objašnjene zajedničke varijanse.

\section{DISKUSIJA}

Čini se da je značaj dominantne noge imao uticaj na definisanje strukture karakteristika eksplozivne sile u odnosu na različite grupe sportova (Tabele 4 i 7). Rezultati dobijeni u ovom istraživanju pokazuju da mjerene karakteristike eksplozivne sile opružača nogu dobijene u bi i unilateralnom režimu naprezanja u odnosu na različite grupe sportova imaju različitu strukturu u funkciji izdvojenog sklopa faktora pod uticajem drugačijih mehanizama u odnosu na trenažne procese u različitim sportskim disciplinama. $\mathrm{Na} \mathrm{Ta}-$ belama 4 i 7 i Slikama 4 i 5 su prikazani izdvojeni faktori u funkciji različitih grupa sportova u odnosu na pol sa aspekta apsolutnih vrijednosti pokazatelja nivoa razvijenosti eksplozivne sile.

$\mathrm{Na}$ osnovu dobijenih rezultata i analiziranih varijabli Prvog faktora na uzorku treniranih ispitanika 
SLIKA 4

Izdvojeni faktori u odnosu na ispitanike muskkog pola.

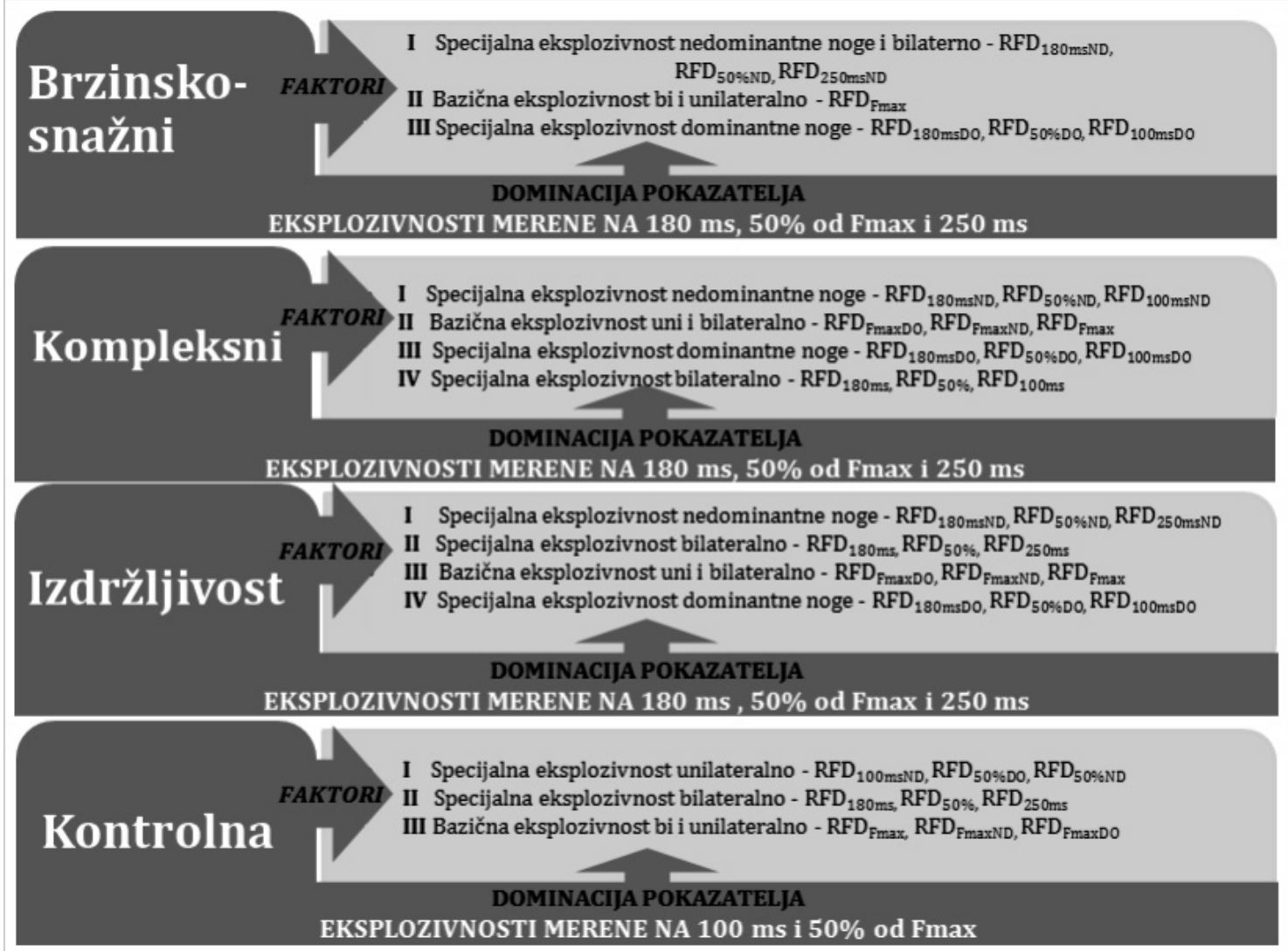

SLIKA 5

Izdvojeni faktori u odnosu na ispitanike ženskog pola.

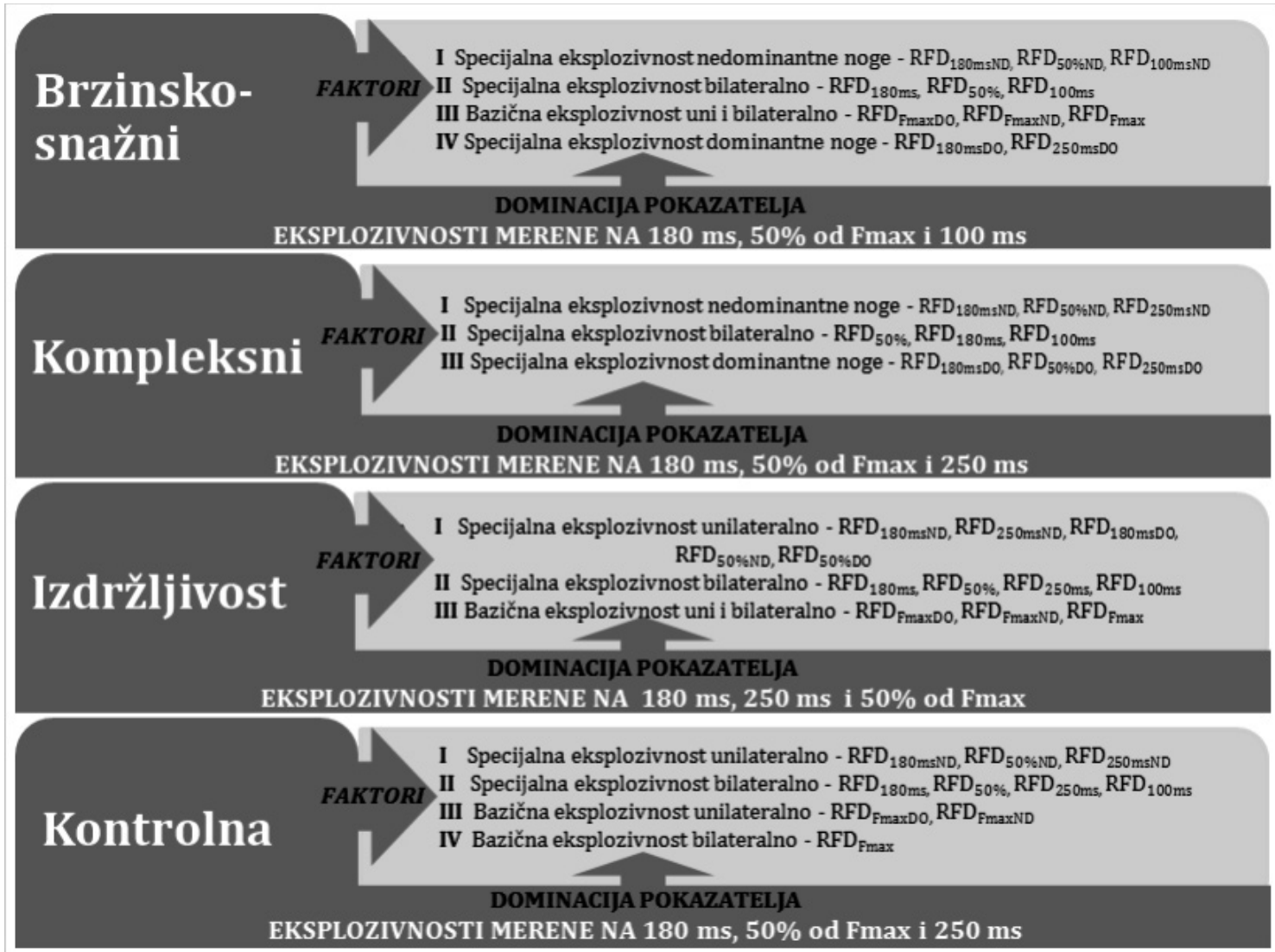


muškog pola možemo zaključiti da se sportisti iz ovih grupa najviše razlikuju, tj. diskriminiše ih najviše eksplozivnost nedominantne noge mjerene na nivou od 180 ms. Razloge, posebno kada je riječ o brzinskosnažnoj i grupi sportova sa kompleksnim ispoljavanjem svih motoričkih svojstava, vjerovatno treba tražiti $\mathrm{u}$ činjenici da je u istraživanju učestvovao veliki broj sportista iz sportskih disciplina gdje dominantna noga igra značajnu ulogu (uloga dominantne noge u skakačkim disciplinama atletike, različitim vrstama skokova sa jedne noge u odbojci, košarci, rukometu, različite vrste šuteva, dodavanja i driblinga u fudbalu, specifičnim stavovima i kretnjama u mačevanju...).

U tim slučajevima često nedominantna noga ne igra značajnu ulogu u uspješnosti izvođenja određenih motoričkih zadataka, pa samim tim ni kontraktilne sposobnosti opružača nogu nisu razvijene na istom/ adekvatnom nivou kod svih pojedinaca. Bazična eksplozivnost je indikator, tj. analogija opšte fizičke pripreme sa aspekta eksplozivnosti. Kako brzinskosnažnu grupu sportova čine vrhunski sportisti ne čudi činjenica da je drugi faktor saturiran indikatorima opšte fizičke pripreme koji je sa aspekta prioriteta u trenažnom procesu date grupe sportista u drugom planu. On zapravo čini bazu za specifični „funkcionalni fundament" za dalji rad na povećanju efikasnosti u sportu. U slučaju vrhunskih sportista brzinskosnažne grupe sportova treba da dominira specijalna fizička priprema i trenažni procesi koji će uticati na visok nivo ispoljavanja eksplozivne sile tokom inicijalne (rane) faze mišićne kontrakcije koja je veoma značajna za uspješno izvođenje eksplozivnih pokreta u grupi brzinsko-snažnih sportova. Upravo je treći faktor saturiran indikatorima usko specifične, tj. specijalizovane fizičke pripreme sa aspekta eksplozivnosti. Specijalna eksplozivnost dominantne noge mjerena na $180 \mathrm{~ms}$ je indikator po kome se sportisti iz ove grupe najmanje razlikuju, tj. diskriminišu. Razlozi dobijenih rezultata kao što je u prethodnom dijelu teksta već spomenuto kod objašnjenja izdvojenih varijabli prvog faktora, treba tražiti u značajnoj ulozi dominantne noge u sportskim disciplinama koje su činile brzinsko-snažnu grupu sportova.

Za razliku od brzinsko-snažne grupe sportista, sportiste iz grupe sportova sa kompleksnim ispoljavanjem svih motoričkih sposobnosti se najmanje razlikuju, tj. najmanje ih diskriminišu specijalna eksplozivnost mjerena u vremenskom intervalu od 180 ms i specifična eksplozivnost bilateralno. Vremenski interval mjeren na 50\% od maksimalne sile predstavlja vreme realizacije $S$ gradienta tj. startnog ubrzanja, dok na $180 \mathrm{~ms}$ predstavlja najkarakterističnije vrijeme kontakta sa tlom tokom trčanja u submaksi- malnom režimu naprezanja, naglih promjena pravaca kretanja i vertikalnih odskoka (Čoh, 2010; Čoh i Bošnjak, 2010; Gruber i Gollhofer, 2004; Haff i saradnici, 2005; Hakkinen, 1991; Ikemoto i saradnici, 2007; Kraska i saradnici, 2009; Zatsiorsky \& Kraemer, 2006). Ovi vremenski intervali su tipični za sportove koji čine grupu sportova sa kompleksnim ispoljavanjem svih motoričkih svojstava pa samim tim ne čudi ni činjenica da su baš indikatori eksplozivnosti u tim vremenskim intervalima izdvojeni kao IV i poslednji faktor ove grupe sportova.

Kako grupu sportova izdržljivosti i kontrolnu grupu čine vrhunski sportisti i fizički aktivni i zdravi ispitanici kod kojih ne dominiraju eksplozivni pokreti, onda ne čudi činjenica da je treći i četvrti faktor, koji je saturiran indikatorima opšte fizičke pripreme po kojima se ispitanici kontrolne grupe i grupe sportova izdržljivosti najmanje razlikuju, tj. najmanje ih diskriminišu i koji su sa aspekta prioriteta u fizičkim aktivnostima datih grupa dominantni.

$\mathrm{Na}$ osnovu dobijenih rezultata i analiziranih varijabli Prvog faktora na uzorku treniranih ispitanika ženskog pola možemo zaključiti da isto kao i kod muškaraca sportisti iz ovih grupa se najviše razlikuju, tj. diskriminiše ih najviše eksplozivnost nedominantne noge merene na nivou od $180 \mathrm{~ms}$. Evidentno je da možemo da pretpostavimo da su razlozi dobijenih rezultata isti, s obzirom da su iste sportske discipline činile i muške i ženske grupe sportova.

Za razliku od muške grupe sportova sa kompleksnim ispoljavanjem svih motoričkih sposobnosti, sportistkinje iz ove grupe se najmanje razlikuju, tj. najmanje ih diskriminišu specijalna eksplozivnost mjerena u vremenskom intervalu od $180 \mathrm{~ms}$ i specifična eksplozivnost dominantne noge.

Dobijeni rezultati indirektno potvrđuju i rezultate našeg ranijeg istraživanja gde su u odnosu na tri grupe različito treniranih sportistkinja, na uzorku apsolutnih i relativnih parametara eksplozivnosti opružača nogu rezultati pokazali razlike u broju, strukturi i sklopu izdvojenih faktora pod uticajem drugačijih mehanizama u odnosu na trenažne procese u različitim sportskim disciplinama (Ivanović i Dopsaj, 2011).

\section{ZAKLJUČCI}

$\mathrm{Na}$ osnovu rezultata istraživanja može se zaključiti da je kod sportista iz različitih grupa sportova oba pola utvrdena i različita faktorska struktura posmatranih indikatora eksplozivnosti.

Rezultati dobijeni u ovom istraživanju pokazuju da mjerene karakteristike eksplozivne sile opružača nogu dobijene u bi i unilateralnom režimu naprezanja u odnosu na različite grupe sportova imaju različitu 
strukturu u funkciji izdvojenog sklopa faktora pod uticajem drugačijih mehanizama u odnosu na trenažne procese u različitim sportskim disciplinama. Sa aspekta utvrđenih razlika u faktorskoj strukturi indikatora za procenu eksplozivnosti opružača nogu u odnosu na različite grupe sportova oba pola još više naglašavaju uticaj adaptacije sa različitim ispoljavanjem karakteristika mišićne sile ali i povezanosti sportske grane i produkcije kontraktilnih karakteristika mišićne sile.

Generalno, i kod muškaraca i kod žena je utvrđeno da je najdominantniji indikator izometrijske eksplozivne sile opružača nogu indikator nivoa razvijenosti ispoljavanja sile nedominantne noge u vremenskom intervalu od 180 ms $\left(\mathrm{RFD}_{180 \mathrm{msND}}\right)$, pa je osnovna preporuka ovog istraživanja da se on priključi bateriji već postojećih standardnih indikatora $\left(\mathrm{F}_{\max }\right.$ i $\left.\mathrm{RFD}_{\mathrm{Fmax}}\right)$ kao najinformativniji specijalni indikator esplozivne sile.

\section{IZJAVA ZAHVALNOSTI}

Rad je realizovan u okviru projekta br. III47015 finansiranog od strane Ministarstva za nauku i tehnološki razvoj Republike Srbije.

\section{LITERATURA}

Andersen, L. L. \& Aagaard, P. (2006). Influence of maximal muscle strength and intrinsic muscle contractile properties on contractile rate of force development. European Journal of Applied Physiology, 96(1), 46-52. doi: 10.1007/s00421005-0070-z; PMid: 16249918

Andersen, L. L., Andersen, J. L., Zebis, M. K., \& Aagaard, P. (2010). Early and late rate of force development: differential adaptive responses to resistance training? Scandinavian Journal of Medicine \& Science in Sports, 20(1), 162-169. doi: 10.1111/j.1600-0838.2009.00933.x

Čoh, M. (2010). Biomechanical characteristics of take off action in high jump - a case study. Serbian Journal of Sports Sciences, 4(4), 127-135.

Čoh, M., \& Bošnjak, G. (2010). Neuro-mišićne karakteristike maksimalne sprinterske brzine [Neuromuscular characteristics of maximum sprint speed]. Sportlogia, 6(1), 28-35. doi: 10.5550 / sgia. 1001028

Dopsaj, M., \& Ivanović, J. (2011). The analysis of the reliability and factorial validity in the basic characteristics of isometric F-t curve of the leg extensors in well trained serbian males and females. Measurement Science Review, 11(5), 165172. doi: 10.2478/v10048-011-0027-9
Gruber, M., \& Gollhofer, A. (2004). Impact of sensorimotor training on the rate of force development and neural activation. European Journal of Applied Physiology, 92(1-2), 98-105. doi: 10.1007/s00421-004-1080-y; PMid: 15024669

Haff, G. G., Carlock, J. M., Hartman, M. J., Kilgore, J. L. , Kawamori, N., Jackson, J. R., ... Stone, M. H. (2005). Force-time characteristics of dynamic and isometric muscle actions of elite women Olympic weightlifters. Journal of Strength and Conditioning Research, 19(4), 741-748. doi: 10.1519/R-15134.1; doi: 10.1519/00124278200511000-00004

Hair, J. F., Rolph, E. A., Ronald, L. T., \& William, C. B. (1998). Multivariate Data Analysis. 5th Ed. New Jersey, NJ: Prentice - Hall, Inc.

Hakkinen, K. (1991). Force production characteristics of leg extensor, trunk flexor and extensor muscles in male and female basketball players. Journal of Sports Medicine and Physical Fitness, 31(3), 325-331.

Hakkinen, K., Komi, P. V., Alen, M., \& Kauhanen, H. (1987). EMG, muscle fibre and force production characteristics during a 1 year training period in elite weight-lifters. European Journal of Applied Physiology, 56(4), 419-427. doi: 10.1007/BF00417769

Ikemoto, Y., Demura, S., Yamaji, S., Minami, M., Nakada, N., \& Uchiyama, M. (2007). Force-time parameters during explosive isometric grip correlate with muscle power. Sport Sciences for Health, 2(2), 64-70. doi: 10.1007/s11332-0070041-3

Ivanović, J., Dopsaj, M., Ćopić, N., \& Nešić, G. (2011). Is there a relation between maximal and explosive leg extensors isometric force? Facta Universitatis Series: Physical Education and Sport, 9(3), 239-254.

Ivanović, J., Dopsaj, M., \& Nešić, G. (2011). Factor Structure differences of indicators for evaluating isometric leg extensors explosive force in female volleyball athletes and different trained female population. British Journal of Sports Medicine, 45(6), 542. doi: 10.1136/ bjsm.2011.084558.26

Kraska, J. M., Ramsey, M. V., Haff, G. G., Fethke, N., Sands, W. A., Stone, M. E., \& Stone, M. H. (2009). Relationship between strength characteristics and unweighted and weighted vertical jump height. International Journal of Sports Physiology and Performance, 4(4), 461-473.

Mero, A. (1988). Force-time characteristics and running velocity of male sprinters during 
acceleration phase of sprinting. Research Quarterly for Exercise \& Sport, 94(2), 94-98. doi: 10.1080/02701367.1988.10605484

Müller, E., Benko, U., Raschner, C. \& Schwamede. (2000). Specific fitness training and testing in competitive sports. Medicine and Science in Sports and Exercisec, 32(1), 216-220. doi: 10.1097/00005768-200001000-00032

Зациорски, В. (1982). Спортивная метрология [Sports metrology]. Москва: Физкультура и спорт.
Zatsiorsky, V. M., \& Kraemer, W. J. (2006). Science and practice of strength training. Champaign, IL: Human Kinetics.

Wilson, G., \& Murphy, A. (1996). Strength diagnosis: The use of test data to determine specific strength training. Journal of Sports Sciences, 14(2), 167-173. doi: 10.1080/02640419608727698; PMid: 8737324

Primljeno: 22. decembra 2012. godine Izmjene primljene: 5. juna 2013. godine

Odobreno: 17. juna, 2013. godine

Korespondencija:

Dr Jelena Ivanović

Šef Odeljenja za analitiku u sportu Zavod za sport i medicinu sporta Republike Srbije

Kneza Višeslava 72, 11030 Beograd, Srbija

Telefon: 00381606410710

Faks: 00381113555288

E-mail: jelena.ivanovic@rzsport.gov.rs 